\title{
Erratum to "Isolation, Characterization and Antimicrobial Resistance Patterns of Lactose-Fermenter Enterobacteriaceae Isolates from Clinical and Environmental Samples" [Open Journal of Medical Microbiology 5 (2015) 169-176]
}

\section{Israa Abdul Jabbar Ibrahim*, Tuqa Abdul Kareem Hameed}

Department of Biology, College of Education for Pure Science Ibn Al-Haitham, University of Baghdad, Baghdad, Iraq

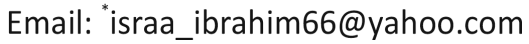

Received 20 September 2015; accepted 23 November 2015; published 26 November 2015

Copyright (C) 2016 by authors and Scientific Research Publishing Inc.

This work is licensed under the Creative Commons Attribution International License (CC BY).

http://creativecommons.org/licenses/by/4.0/

c) (i) Open Access

The original online version of this article (Ibrahim, I.A.J. and Hameed, T.A.K. (2015) Isolation, Characterization and Antimicrobial Resistance Patterns of Lactose-Fermenter Enterobacteriaceae Isolates from Clinical and Environmental Samples. Open Journal of Medical Microbiology, 5, 169-176. http://dx.doi.org/10.4236/ojmm.2015.54021) was mistaken of the total isolates number in Table $2 \&$ Table 3 , Figure $1 \&$ Figure 2 . The authors wish to correct the errors to:

Table 2. Bacterial species isolated from environmental specimens.

\begin{tabular}{cccc}
\hline No. & Species & Number/(\%) & Environmental specimens \\
\hline 1 & Escherichia coli & $46(54.1)$ & Water, chicken feces, soil \\
2 & Klebsiella pneumoniae & $31(36.4)$ & Water, chicken feces \\
3 & K. oxytoca & $2(2.3)$ & Chicken feces \\
4 & Raoultella planticola & $1(1.17)$ & Water \\
5 & Chryseomonas luteola & $1(1.17)$ & Soil \\
6 & Burkholderia cepacia & $1(1.17)$ & Soil \\
7 & Aeromonas hydrophila & $1(1.17)$ & Soil \\
8 & Streptococccus faecalis & $2(2.3)$ & Soil, water \\
& Total & 85 & \\
\hline
\end{tabular}

${ }^{*}$ Corresponding author. 
Table 3. Bacterial species isolated from clinical specimens.

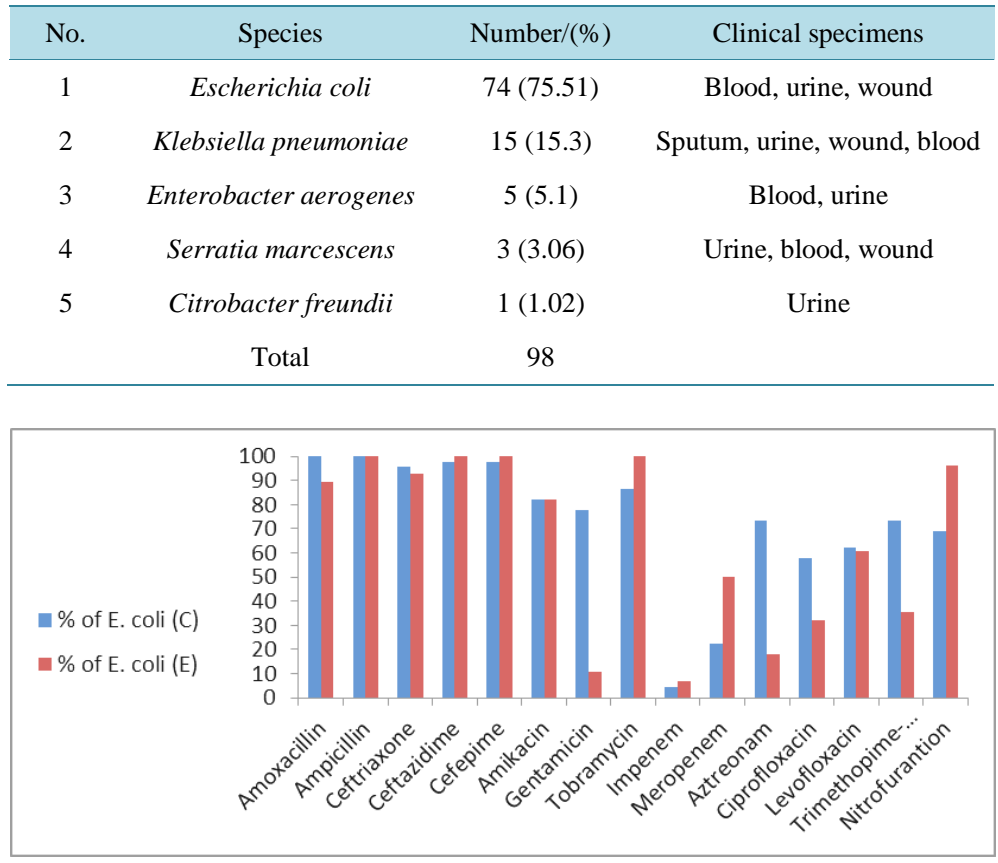

Figure 1. The percentage of antimicrobial resistance patterns of E. coli isolates (C: clinical specimens, E: environmental specimens).

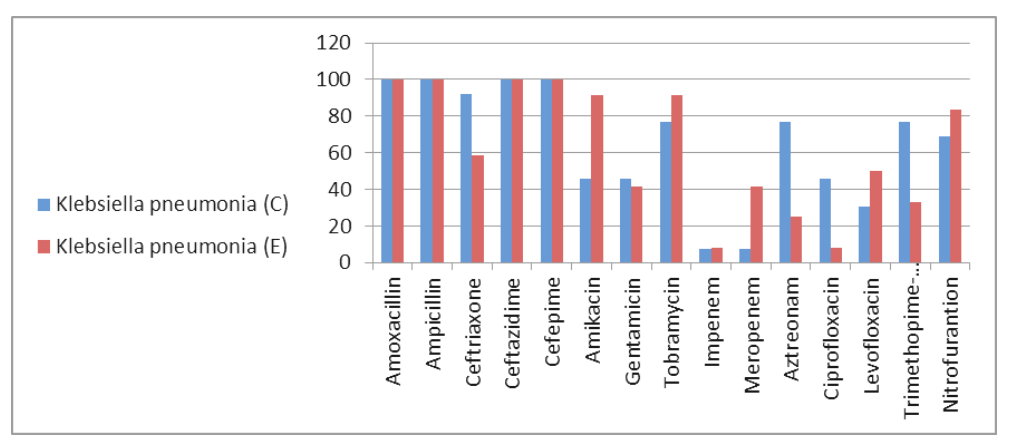

Figure 2. The percentage of antimicrobial resistance patterns of K. pneumoniae isolates (C: clinical specimens, E: environmental specimens). 